\title{
SISTEM PAKAR FUZZY PENENTUAN KUALITAS KAKAO
}

\section{Oleh}

\author{
Mohammad Yazdi ${ }^{1)}$, Gunawan Feri Handono ${ }^{2)}$ \\ ${ }^{1), 2)}$ Jurusan Matematika, Fakultas MIPA, Universitas Tadulako \\ Kampus Bumi Tadulako Tondo
}

Jl. Soekarno Hatta Km. 9 Telp : (0451) 422611 - 422355 Fax : (0451) 422844

email : yazdi.diyanara@gmail.com ${ }^{1)}$,gunawan_mail@yahoo.co.id ${ }^{2}$ Palu - Sulawesi Tengah 94118

\begin{abstract}
ABSTRAK
Kakao (Theobroma cocoa $L$ ) adalah salah satu komoditas yang mempunyai nilai ekonomis tinggi terutama untuk ekspor dan sangat potensial untuk dikembangkan menjadi komoditas ekspor unggulan. Faktor yang paling menentukan terhadap keberhasilan produk kakao untuk diterima di pasar adalah faktor kualitas. Kualitas kakao dipengaruhi oleh kandungan Kadar air, Jamur, Kotoran dan Jumlah biji dalam seratus gram. Pasar internasional memiliki tuntutan kualitas yang sangat baik, sementara untuk kualitas dibawahnya diperuntukkan bagi pasar lokal. Penelitian ini bertujuan menghasilkan suatu sistem pakar untuk menentukan kualitas kakao. FIS yang digunakan untuk penentuan kualitas kakao adalah metode Mamdani. Metode mamdani memiliki 4 tahapan yaitu: pembentukan himpunan fuzzy, aplikasi fungsi implikasi, komposisi dan defuzzy. Hasil dari penelitian adalah sebuah Sistem Pakar Fuzzy yang mampu menentukan kualitas kakao berdasarkan kriteria-kriteria yang mempengaruhi kualitas kakao.
\end{abstract}

Kata kunci : Kakao, Kualitas, Sistem Pakar Fuzzy, Fuzzy Inferensi Sistem, Mamdani

\section{PENDAHULUAN}

Kakao merupakan salah satu komoditas perkebunan yang sesuai untuk perkebunan rakyat, karena tanaman ini dapat berbunga dan berbuah sepanjang tahun, sehingga dapat menjadi sumber pendapatan harian atau mingguan bagi Petani. Selain itu, komoditi tanaman perkebunan merupakan sumber devisa bagi negara dan rangkaian kegiatan produksinya cukup banyak menyerap tenaga kerja.

Dalam agrobisnis kakao ada beberapa kendala yang dihadapi, khususnya dalam peningkatan produktivitas dan kualitas yang dihasilkan antara lain adalah masih mempergunakan teknologi tradisional dengan bahan tanaman yang tidak berasal dari klon atau biji yang terpilih dan dengan budidaya yang kurang memadai, serta serangan organisme pengganggu tanaman (OPT) berupa hama dan penyakit (Darwis.V dan Agustin.N.K, 2003).

Propinsi Sulawesi tengah merupakan sentra produksi kakao Indonesia. Kabupaten Sigi-Biromaru merupakan kabupaten yang ada di wilayah propinsi sentra produksi kakao Indonesia dan lahan produksi kakao yang cukup luas serta 
kualitas biji kakao kering yang belum diketahui, maka sepantasnya jika kualitas biji kakao kering di kabupaten tersebut diketahui. Selain itu, penulis ingin mengaplikasikan logika fuzzy untuk menentukan kualitas kakao dengan melibatkan beberapa pakar, sehingga penulis mengangkat judul "Sistem Pakar Fuzzy Penentuan Kualitas Kakao

\subsection{Rumusan Masalah}

Adapun rumusan masalah dalam penelitian ini adalah bagaimana menentukan kualitas kakao dengan menggunakan Sistem Pakar fuzzy.

\subsection{Tujuan Penelitian}

Tujuan yang ingin dicapai dalam penelitian ini adalah menghasilkan sistem pakar fuzzy yang dapat digunakan dalam proses menentukan kualitas kakao.

\subsection{Manfaat Penelitian}

1) Penelitian ini diharapkan dapat bermanfaat, bagi :

2) Pemerintah daerah, sebagai acuan untuk memikirkan dan memberikan perhatian yang lebih kepada para petani kakao.

3) Formulator perkebunan, sebagai dasar dalam mendapatkan strategi untuk meningkatkan kualitas hasil perkebunan kakao.

4) Pengembangan penelitian selanjutnya.

\subsection{Batasan Masalah}

1) Penelitian ini terbatas pada teknik Sistem pakar fuzzy dengan fuzzy inferensi system (FIS) metode Mamdani.

2) Defuzzyfikasi yang digunakan adalah LOM (Largest Of Maximum)

3) Data kakao yang diambil adalah data biji kakao kering.

\section{LANDASAN TEORI}

\subsection{Kakao}

Pada tahun 1519 Bangsa Indian Maya dan Astec di Amerika Tengah telah diketahui mempunyai pengetahuan tentang bercocok tanam dan pengolahan biji kakao. Pengolahan biji kakao kering hingga menjadi minuman, telah mampu membuat ekstrak biji kakao. Minuman yang menggunakan serbuk biji kakao kering disebut juga dengan minuman dewa-dewa. Oleh sebab itu Linaeus pada tahun 1720 menamakan tanaman coklat menjadi Theobroma cocoa L, dimana Theobroma dalam bahasa latin mempunyai arti makanan dewa-dewa (foods of the God).

Cokelat (Theobroma cocoa L) atau lazim pula disebut tanaman kakao, adalah penghasil bahan penyedap (penyegar), seperti halnya kopi dan teh. kakao sudah mulai di manfaatkan bijinya untuk minuman oleh bangsa Indian Maya beberapa abad sebelum masehi. Komoditas ini dikenal oleh dunia hingga penanamannya meluas setelah bangsa kulit putih menguasai benua Amerika (Mayang. I.T.,2010). 


\subsection{Sistem Pakar}

\subsubsection{Definisi}

Secara umum sistem pakar (expert system) adalah sistem yang berusaha mengadopsi pengetahuan manusia ke komputer, agar komputer dapat menyelesaikan masalah seperti yang biasa dilakukan oleh para ahli. Ada beberapa definisi tentang sistem pakar antara lain:

1. Menurut Durkin, sistem pakar adalah suatu program komputer yang dirancang untuk memodelkan kemampuan penyelesaian masalah yang dilakukan oleh seorang pakar (Kusumadewi, S.2003).

2. Menurut Ignizio, sistem pakar adalah suatu model dan prosedur yang berkaitan dalam suatu domain tertentu yang mana tingkat keahliannya dapat dibandingkan dengan keahlian seorang pakar (Kusumadewi, S.2003).

3. Menurut Giarratano dan Riley, Sistem pakar adalah suatu sistem komputer yang bisa menyamai atau meniru kemampuan seorang pakar (Kusumadewi, S.2003).

\subsubsection{Struktur Sistem Pakar}

Sistem pakar terdiri-dari 2 bagian pokok, yaitu: lingkungan pengembangan (development environment) dan lingkungan konsultasi (consultation environment). Lingkungan pengembangan digunakan sebagai pembangun sistem pakar baik dari segi pembangun komponen maupun basis pengetahuan. Lingkungan konsultasi digunakan oleh seseorang yang bukan ahli untuk berkonsultasi (Kusumadewi,S.2003).

\subsection{Logika fuzzy}

\subsubsection{Himpunan Fuzzy}

Pada tahun 1965 Profesor Lotfi Asker Zadeh mempublikasikan karya ilmiahnya berjudul "fuzzy sets". Terobosan baru tersebut merupakan konsep perluasan "himpunan" klasik menjadi himpunan kabur ( fuzzy sets), dalam arti bahwa himpunan klasik (crisp set) merupakan kejadian khusus dari himpunan yang kabur. Menurut George Cantor (1845-1918), himpunan didefinisikan sebagai suatu koleksi obyek-obyek yang terdefinisi secara tegas. Dengan demikian, suatu himpunan $\mathrm{A}$ dalam semesta $\mathrm{X}$ dapat didefinisikan dengan menggunakan suatu fungsi $x_{A}(\mathrm{x}): \mathrm{X} \rightarrow\{0,1\}$, yang disebut fungsi karakteristik dari himpunan $\mathrm{A}$, dimana untuk setiap $x \in \mathrm{X}$

$$
x_{A}(X)= \begin{cases}1, \text { wntuk } & x \in A \\ 0, \text { untuk } & x \notin A\end{cases}
$$

Dengan memperluas konsep fungsi karakteristik itu, Zadeh mendefinisikan himpunan fuzzy dengan menggunakan apa yang disebutnya Fungsi Keanggotaan (membership function), yang nilainya berada dalam selang tertutup [0,1]. Jadi keanggotaan dalam himpunan fuzzy tidak lagi merupakan sesuatu yang tegas (yaitu anggota atau bukan anggota), melainkan sesuatu yang berderajat atau bergradasi secara kontinu (Susilo.F.,2006). 


\subsubsection{Metode Mamdani}

Metode Mamdani sering dikenal sebagai metode max-min. Metode ini dikenalkan oleh Ebrahim Mamdani pada tahun 1975. Untuk mendapatkan output diperlukan 4 tahapan:

1. Pembentukan himpunan fuzzy

Pada metode mamdani, baik variabel input maupun variabel output dibagi menjadi satu atau lebih himpunan fuzzy

2. Aplikasi fungsi implikasi ( aturan )

Pada metode mamdani, fungsi implikasi yang di gunakan adalah Min (Minimum). Fungsi ini akan memotong output himpunan fuzzy.

3. Komposisi aturan

Tidak seperti penalaran monoton apabila sistem terdiri dari beberapa aturan, Maka inferensi diperoleh dari kumpulan dan korelasi antar aturan. Ada 3 metode yang digunakan dalam melakukan inferensi fuzzy yaitu : Max, additive dan probabilistic OR (probor). Dalam penelitian ini, penulis menggunakan metode Max.Pada metode ini solusi himpunan fuzzy diperoleh dengan cara mengambil nilai maximum aturan, kemudian menggunakannya untuk memodifikasi daerah fuzzy dan mengaplikasikannya ke output dengan menggunakan operator OR (union). Jika semua proposisi telah di evaluasi, Maka output akan berisi suatu himpunan fuzzy yang merefleksikan kontribusi dari tiap-tiap proposisi. Secara umum dapat dituliskan :

$\mu_{s f}\left[x_{i}\right]=\max \left(\mu_{s f}\left[x_{i}\right], x_{k f}\left[x_{i}\right]\right)$

Dengan:

$\mu_{s f}\left[x_{i}\right]=$ Nilai keanggotaan solusi fuzzy sampai aturan ke-i;

$\mu_{k f}\left[x_{i}\right]=$ Nlai keanggotaan konsekuen fuzzy aturan ke-i;

4. Penegasan ( defuzzy )

Input dari proses defuzzy adalah suatu himpunan fuzzy yang diperoleh dari komposisi aturan-aturan fuzzy, sedangkan output yang dihasilkan merupakan suatu bilangan pada domain himpunan fuzzy tersebut (Dewi,T and Purnomo,H.2004). Sehingga jika diberikan suatu himpunan fuzzy dalam range tertentu, maka harus dapat diambil suatu nilai crisp tertentu sebagai output. Dalam penelitian ini, penulis menggunakan metode LOM (largest of maximum). Pada metode ini, solusi crisp diperoleh dengan cara mengambil nilai terbesar dari domain yang memiliki nilai keanggotaan maksimum.

\section{METODE PENELITIAN}

\subsection{Alat dan Bahan}

Adapun Alat yang digunakan dalam Penelitian ini adalah sebagai berikut :

1. PC dengan Spesifikasi : Processor Pentium ${ }^{\circledR}$ Dual-Core T4400, CPU $2.20 \mathrm{GHz}, 800 \mathrm{MHz}, 1 \mathrm{MB}$ L2 Cache, Harddisk $240 \mathrm{~GB}$ HDD, dan 800 MB DDR2. 
2. Sistem operasi Windows XP Profesional Service Pack 3.

3. Software Mathlab 7.

\subsection{Sumber dan Jenis Data}

Sumber data yang digunakan dalam penelitian ini adalah data primer yang berupa data kuantitatif biji kakao kering.

\subsection{Teknik Pengolahan Data}

Data aktual tentang kakao yang telah diperoleh, kemudian diolah menggunakan FIS dengan metode mamdani.

\subsection{Prosedur Penelitian}

Prosedur penelitian dilaksanakan sebagai berikut:

1. Memulai penelitian

2. Memilih pakar

3. Konsultasi pakar mengacu pada SNI

4. Mengumpulkan data biji kakao kering

5. Proses pengolahan data terdiri dari empat tahapan yaitu:
a. Pembentukan himpunan fuzzy.
b. Aplikasi fungsi implikasi.
c. Komposisi aturan.
d. Penegasan(defuzzy).
e. Implementasi Sistem Pakar

6. Hasil

\section{HASIL DAN PEMBAHASAN}

\subsection{Hasil}

Bab ini akan menjelaskan tahap-tahap untuk mendapatkan hasil atau untuk mengetahui kualitas kakao kabupaten sigi-biromaru dengan menggunakan logika fuzzy Mamdani dan metode pada proses defuzzifikasi adalah LOM (large of maximum). Terdapat kerangka sistem pakar Fuzzy berdasarkan Metode Mamdani yang menjadi acuan penetapan keputusan penentuan kualitas kakao. Kerangka sistem pakar fuzzy dapat digambarkan sebagai berikut :

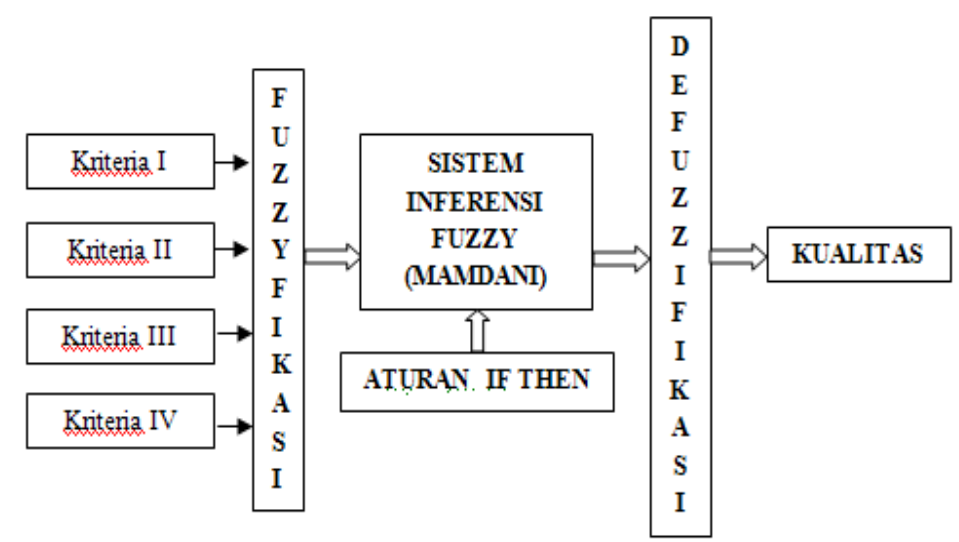

Gambar 1 Kerangka sistem pakar fuzzy Penentuan Kualitas Kako 
Dalam menjabarkan kerangka tersebut dibuatkan beberapa tahapan dalam penentuan kualitas kakao kabupaten sigi-biromaru, yaitu sebagai berikut:

\subsubsection{Pemilihan pakar}

Pemilihan pakar dalam penelitian ini didasarkan pada keahlian pakar dalam bidang pengendalian hama dan penyakit tumbuhan kakao. Berdasarkan survey di lokasi penelitian tepatnya wilayah kabupaten Sigi Biromaru, maka kami memilih formulator pertanian dan file asistan (FA) PT. kresna Kimia sebagai pakar, dengan ketentuan-ketentuan sebagai berikut dibawah ini:

\subsubsection{Konsultasi Pakar}

Konsultasi pakar digunakan untuk menentukan faktor variabel yang menjadi kriteria dalam penilaian kualitas kakao dan untuk mendapatkan aturanaturan yang dibutuhkan dalam proses fuzifikasi yang mengacu pada Standar Nasional Indonesia (SNI).

\subsubsection{Kriteria penentu kualitas kakao}

Terdapat 4 kriteria yang diperoleh melalui konsultasi dengan pakar yaitu:

Tabel 1 Tabel kriteria kualitas kakao

\begin{tabular}{|c|c|c|c|c|}
\hline \multirow{2}{*}{ Kadar } & \multicolumn{4}{|c|}{ Kriteria } \\
\cline { 2 - 5 } & Kadar Air & Jamur & Kotoran & $\begin{array}{c}\text { Biji/100 } \\
\text { gr }\end{array}$ \\
\hline Rendah & $6 \%$ & $2 \%$ & $1 \%$ & 86 \\
\hline Sedang & $7 \%$ & $4 \%$ & $2 \%$ & 103 \\
\hline Tinggi & $8 \%$ & $6 \%$ & $3 \%$ & 120 \\
\hline
\end{tabular}

\subsubsection{Aturan}

Terdapat 81 aturan yang diperoleh melalui konsultasi dengan pakar yaitu:

[R1] if (kadar air is rendah) and (jamur is rendah) and (kotoran is rendah) and (Biji/100gr is rendah) then (kualitas is sangat baik)

[R2] if (kadar air is rendah) and (jamur is rendah) and (kotoran is rendah) and (Biji/100gr is sedang) then (kualitas is baik)

[R3] if (kadar air is rendah) and (jamur is rendah) and (kotoran is rendah) and (Biji/100gr is tinggi) then (kualitas is baik)

[R4] if (kadar air is rendah) and (jamur is rendah) and (kotoran is sedang) and (Biji/100gr is rendah) then (kualitas is baik)

[R5] if (kadar air is rendah) and (jamur is rendah) and (kotoran is sedang) and (Biji/100gr is sedang) then (kualitas is baik)

[R6] if (kadar air is rendah) and (jamur is rendah) and (kotoran is sedang) and (Biji/100gr is tinggi) then (kualitas is kurang baik) 
[R7] if (kadar air is rendah) and (jamur is rendah) and (kotoran is tinggi) and (Biji/100gr is rendah) then (kualitas is kurang baik)

[R8] if (kadar air is rendah) and (jamur is rendah) and (kotoran is tinggi) and (Biji/100gr is sedang) then (kualitas is Kurang baik)

[R9] if (kadar air is rendah) and (jamur is rendah) and (kotoran is tinggi) and (Biji/100gr is tinggi) then (kualitas is buruk)

[R10] if (kadar air is rendah) and (jamur is sedang) and (kotoran is rendah) and (Biji/100gr is rendah) then (kualitas is sangat baik)

[R11] if (kadar air is rendah) and (jamur is sedang) and (kotoran is rendah) and (Biji/100gr is sedang) then (kualitas is baik)

[R12] if (kadar air is rendah) and (jamur is sedang) and (kotoran is rendah) and (Biji/100gr is tinggi) then (kualitas is kurang baik)

[R13] if (kadar air is rendah) and (jamur is sedang) and (kotoran is sedang) and (Biji/100gr is rendah) then (kualitas is baik)

[R14] if (kadar air is rendah) and (jamur is sedang) and (kotoran is sedang) and (Biji/100gr is sedang) then (kualitas is baik)

[R15] if (kadar air is rendah) and (jamur is sedang) and (kotoran is sedang) and (Biji/100gr is tinggi) then (kualitas is kurang baik)

[R16] if (kadar air is rendah) and (jamur is sedang) and (kotoran is tinggi) and (Biji/100gr is rendah) then (kualitas is kurang baik)

[R17] if (kadar air is rendah) and (jamur is sedang) and (kotoran is tinggi) and (Biji/100gr is sedang) then (kualitas is kurang baik)

[R18] if (kadar air is rendah) and (jamur is sedang) and (kotoran is tinggi) and (Biji/100gr is tinggi) then (kualitas is buruk)

[R19] if (kadar air is rendah) and (jamur is tinggi) and (kotoran is rendah) and (Biji/100gr is rendah) then (kualitas is baik)

[R20] if (kadar air is rendah) and (jamur is tinggi) and (kotoran is rendah) and (Biji/100gr is sedang) then (kualitas is baik)

[R21] if (kadar air is rendah) and (jamur is tinggi) and (kotoran is rendah) and (Biji/100gr is tinggi) then (kualitas is kurang baik)

[R22] if (kadar air is rendah) and (jamur is tinggi) and (kotoran is sedang) and (Biji/100gr is rendah) then (kualitas is baik)

[R23] if (kadar air is rendah) and (jamur is tinggi) and (kotoran is sedang) and (Biji/100gr is sedang) then (kualitas is baik)

[R24] if (kadar air is rendah) and (jamur is tinggi) and (kotoran is sedang) and (Biji/100gr is tinggi) then (kualitas is kurang baik) 
[R25] if (kadar air is rendah) and (jamur is tinggi) and (kotoran is tinggi) and (Biji/100gr is rendah) then (kualitas is kurang baik)

[R26] if (kadar air is rendah) and (jamur is tinggi) and (kotoran is tinggi) and (Biji/100gr is sedang) then (kualitas is buruk)

[R27] if (kadar air is rendah) and (jamur is tinggi) and (kotoran is tinggi) and (Biji/100gr is tinggi) then (kualitas is buruk)

[R28] if (kadar air is sedang) and (jamur is rendah) and (kotoran is rendah) and (Biji/100gr is rendah) then (kualitas is sangat baik)

[R29] if (kadar air is sedang) and (jamur is rendah) and (kotoran is rendah) and (Biji/100gr is sedang) then (kualitas is baik)

[R30] if (kadar air is sedang) and (jamur is rendah) and (kotoran is rendah) and (Biji/100gr is tinggi) then (kualitas is kurang baik)

[R31] if (kadar air is sedang) and (jamur is rendah) and (kotoran is sedang) and (Biji/100gr is rendah) then (kualitas is baik)

[R32] if (kadar air is sedang) and (jamur is rendah) and (kotoran is sedang) and (Biji/100gr is sedang) then (kualitas is baik)

[R33] if (kadar air is sedang) and (jamur is rendah) and (kotoran is sedang) and (Biji/100gr is tinggi) then (kualitas is kurang baik)

[R34] if (kadar air is sedang) and (jamur is rendah) and (kotoran is tinggi) and (Biji/100gr is rendah) then (kualitas is kurang baik)

[R35] if (kadar air is sedang) and (jamur is rendah) and (kotoran is tinggi) and (Biji/100gr is sedang) then (kualitas is kurang baik)

[R36] if (kadar air is sedang) and (jamur is rendah) and (kotoran is tinggi) and (Biji/100gr is tinggi) then (kualitas is buruk)

[R37] if (kadar air is sedang) and (jamur is sedang) and (kotoran is rendah) and (Biji/100gr is rendah) then (kualitas is baik)

[R38] if (kadar air is sedang) and (jamur is sedang) and (kotoran is rendah) and (Biji/100gr is sedang) then (kualitas is baik)

[R39] if (kadar air is sedang) and (jamur is sedang) and (kotoran is rendah) and (Biji/100gr is tinggi) then (kualitas is kurang baik)

[R40] if (kadar air is sedang) and (jamur is sedang) and (kotoran is sedang) and (Biji/100gr is rendah) then (kualitas is baik)

[R41] if (kadar air is sedang) and (jamur is sedang) and (kotoran is sedang) and (Biji/100gr is sedang) then (kualitas is baik)

[R42] if (kadar air is sedang) and (jamur is sedang) and (kotoran is sedang) and (Biji/100gr is tinggi) then (kualitas is kurang baik) 
[R43] if (kadar air is sedang) and (jamur is sedang) and (kotoran is tinggi) and (Biji/100gr is rendah) then (kualitas is kurang baik)

[R44] if (kadar air is sedang) and (jamur is sedang) and (kotoran is tinggi) and (Biji/100gr is sedang) then (kualitas is kurang baik)

[R45] if (kadar air is sedang) and (jamur is sedang) and (kotoran is tinggi) and (Biji/100gr is tinggi) then (kualitas is buruk)

[R46] if (kadar air is sedang) and (jamur is tinggi) and (kotoran is rendah) and (Biji/100gr is rendah) then (kualitas is baik)

[R47] if (kadar air is sedang) and (jamur is tinggi) and (kotoran is rendah) and (Biji/100gr is sedang) then (kualitas is baik)

[R48] if (kadar air is sedang) and (jamur is tinggi) and (kotoran is rendah) and (Biji/100gr is tinggi) then (kualitas is kurang baik)

[R49] if (kadar air is sedang) and (jamur is tinggi) and (kotoran is sedang) and (Biji/100gr is rendah) then (kualitas is baik)

[R50] if (kadar air is sedang) and (jamur is tinggi) and (kotoran is sedang) and (Biji/100gr is sedang) then (kualitas is baik)

[R51] if (kadar air is sedang) and (jamur is tinggi) and (kotoran is sedang) and (Biji/100gr is tinggi) then (kualitas is kurang baik)

[R52] if (kadar air is sedang) and (jamur is tinggi) and (kotoran is tinggi) and (Biji/100gr is rendah) then (kualitas is kurang baik)

[R53] if (kadar air is sedang) and (jamur is tinggi) and (kotoran is tinggi) and (Biji/100gr is sedang) then (kualitas is kurang baik)

[R54] if (kadar air is sedang) and (jamur is tinggi) and (kotoran is tinggi) and (Biji/100gr is tinggi) then (kualitas is buruk)

[R55] if (kadar air is tinggi) and (jamur is rendah) and (kotoran is rendah) and (Biji/100gr is rendah) then (kualitas is baik)

[R56] if (kadar air is tinggi) and (jamur is rendah) and (kotoran is rendah) and (Biji/100gr is sedang) then (kualitas is baik)

[R57] if (kadar air is tinggi) and (jamur is rendah) and (kotoran is rendah) and (Biji/100gr is tinggi) then (kualitas is kurang baik)

[R58] if (kadar air is tinggi) and (jamur is rendah) and (kotoran is sedang) and (Biji/100gr is rendah) then (kualitas is baik)

[R59] if (kadar air is tinggi) and (jamur is rendah) and (kotoran is sedang) and (Biji/100gr is sedang) then (kualitas is baik)

[R60] if (kadar air is tinggi) and (jamur is rendah) and (kotoran is sedang) and (Biji/100gr is tinggi) then (kualitas is kurang baik) 
[R61] if (kadar air is tinggi) and (jamur is rendah) and (kotoran is tinggi) and (Biji/100gr is rendah) then (kualitas is kurang baik)

[R62] if (kadar air is tinggi) and (jamur is rendah) and (kotoran is tinggi) and (Biji/100gr is sedang) then (kualitas is kurang baik)

[R63] if (kadar air is tinggi) and (jamur is rendah) and (kotoran is tinggi) and (Biji/100gr is tinggi) then (kualitas is buruk)

[R64] if (kadar air is tinggi) and (jamur is sedang) and (kotoran is rendah) and (Biji/100gr is rendah) then (kualitas is baik)

[R65] if (kadar air is tinggi) and (jamur is sedang) and (kotoran is rendah) and (Biji/100gr is sedang) then (kualitas is baik)

[R66] if (kadar air is tinggi) and (jamur is sedang) and (kotoran is rendah) and (Biji/100gr is tinggi) then (kualitas is kurang baik)

[R67] if (kadar air is tinggi) and (jamur is sedang) and (kotoran is sedang) and (Biji/100gr is rendah) then (kualitas is baik)

[R68] if (kadar air is tinggi) and (jamur is sedang) and (kotoran is sedang) and (Biji/100gr is sedang) then (kualitas is kurang baik)

[R69] if (kadar air is tinggi) and (jamur is sedang) and (kotoran is sedang) and (Biji/100gr is tinggi) then (kualitas is kurang baik)

[R70] if (kadar air is tinggi) and (jamur is sedang) and (kotoran is tinggi) and (Biji/100gr is rendah) then (kualitas is kurang baik)

[R71] if (kadar air is tinggi) and (jamur is sedang) and (kotoran is tinggi) and (Biji/100gr is sedang) then (kualitas is kurang baik)

[R72] if (kadar air is tinggi) and (jamur is sedang) and (kotoran is tinggi) and (Biji/100gr is tinggi) then (kualitas is buruk)

[R73] if (kadar air is tinggi) and (jamur is tinggi) and (kotoran is rendah) and (Biji/100gr is rendah) then (kualitas is kurang baik)

[R74] if (kadar air is tinggi) and (jamur is tinggi) and (kotoran is rendah) and (Biji/100gr is sedang) then (kualitas is kurang baik)

[R75] if (kadar air is tinggi) and (jamur is tinggi) and (kotoran is rendah) and (Biji/100gr is tinggi) then (kualitas is buruk)

[R76] if (kadar air is tinggi) and (jamur is tinggi) and (kotoran is sedang) and (Biji/100gr is rendah) then (kualitas is kurang baik)

[R77] if (kadar air Is tinggi) and (jamur is tinggi) and (kotoran is sedang) and (Biji/100gr is sedang) then (kualitas is kurang baik) 
[R78] if (kadar air is tinggi) and (jamur is tinggi) and (kotoran is sedang) and (Biji/100gr is tinggi) then (kualitas is buruk)

[R79] if (kadar air is tinggi) and (jamur is tinggi) and (kotoran is tinggi) and (Biji/100gr is rendah) then (kualitas is buruk)

[R80] if (kadar air is tinggi) and (jamur is tinggi) and (kotoran is tinggi) and (Biji/100gr is sedang) then (kualitas is buruk)

[R81] if (kadar air is tinggi) and (jamur is tinggi) and (kotoran is tinggi) and (Biji/100gr is tinggi) then (kualitas is sangat buruk)

\subsubsection{Pengumpulan data aktual}

Data yang penulis dapatkan adalah data yang diambil dari 4 tempat berbeda di kabupaten Sigi-Biromaru. Empat tempat pengambilan data di Kabupaten SigiBiromaru tersebut adalah penampung kakao di Biromaru, pengumpul di Desa Palolo, petani di Desa Loru dan petani di Desa Palolo. Data yang diperoleh dari 4 tempat tersebut dapat dilihat pada Tabel berikut:

Table 2 Data kualitas kakao

\begin{tabular}{|l|c|c|c|c|c|}
\hline Kriteria & $\begin{array}{c}\text { Penampung di } \\
\text { biromaru }\end{array}$ & $\begin{array}{c}\text { Pengumpul } \\
\text { di desa } \\
\text { palolo }\end{array}$ & $\begin{array}{c}\text { Petani } \\
\text { di desa } \\
\text { loru }\end{array}$ & $\begin{array}{c}\text { Petani } \\
\text { di desa } \\
\text { palolo }\end{array}$ & $\begin{array}{c}\text { Rata- } \\
\text { rata }\end{array}$ \\
\hline Kadar Air & 7,6 & 7 & 7,5 & 6 & 7,025 \\
\hline Kotoran & 1 & 1 & 1 & 1 & 1 \\
\hline Jamur & 2,5 & 2 & 2,5 & 2 & 2,25 \\
\hline Biji/100gram & 116 & 115 & 114 & 115 & 115 \\
\hline
\end{tabular}

\subsubsection{Semesta pembiaraan dan Himpunan fuzzy}

Semesta pembicaraan pada penelitian ini di ambil dari nilai terkecil dan nilai terbesar yang membentuk suatu interval tertentu . yaitu:

Untuk himpunan fuzzy, terdapat 5 variabel fuzzy yang akan dimodelkan,

1. Kadar air; terdiri atas 3 himpunan fuzzy, yaitu : RENDAH, SEDANG dan TINGGI.

2. Jamur; terdiri atas 3 himpunan fuzzy, yaitu: RENDAH, SEDANG dan TINGGI.

3. Kotoran; terdiri atas 3 himpunan fuzzy, yaitu: RENDAH, SEDANG dan TINGGI.

4. Biji/100gr; terdiri atas 3 himpunan fuzzy, yaitu: RENDAH, SEDANG dan TINGGI.

5. Kualitas; terdiri atas 5 himpunan fuzzy, yaitu: SANGAT BURUK, BURUK, KURANG BAIK, BAIK dan SANGAT BAIK. 
Tabel 3 Himpunan fuzzy

\begin{tabular}{|c|c|c|c|c|}
\hline Fungsi & Nama Variabel & $\begin{array}{c}\text { Semesta } \\
\text { Pembicaraan }\end{array}$ & Nama himpunan & Domain \\
\hline \multirow{12}{*}{ Input } & \multirow{3}{*}{ Kadar Air } & \multirow{3}{*}{$5-9$} & Rendah & {$[5,7]$} \\
\hline & & & Sedang & {$[6,8]$} \\
\hline & & & Tinggi & {$[7,9]$} \\
\hline & \multirow{3}{*}{ Jamur } & \multirow{3}{*}{$0-8$} & Rendah & {$[0,4]$} \\
\hline & & & Sedang & {$[2,6]$} \\
\hline & & & Tinggi & {$[4,8]$} \\
\hline & \multirow{3}{*}{ Kotoran } & \multirow{3}{*}{$0-4$} & Rendah & {$[0,2]$} \\
\hline & & & Sedang & {$[1,3]$} \\
\hline & & & Tinggi & {$[2,4]$} \\
\hline & \multirow{3}{*}{ Biji/100 gram } & \multirow{3}{*}{$69-137$} & Rendah & {$[69,103]$} \\
\hline & & & Sedang & {$[86,120]$} \\
\hline & & & Tinggi & {$[103,137]$} \\
\hline \multirow{5}{*}{ output } & \multirow{5}{*}{ Kualitas Kakao } & \multirow{5}{*}{$0-1,2$} & Sangat buruk & {$[0,0.4]$} \\
\hline & & & Buruk & {$[0.2,0.6]$} \\
\hline & & & Kurang baik & {$[0.4,0.8]$} \\
\hline & & & Baik & {$[0.6,1]$} \\
\hline & & & Sangat baik & {$[0.8,1]$} \\
\hline
\end{tabular}

\subsubsection{Variabel Kadar Air}

Dengan menggunakan representasi kurva bentuk segitiga:

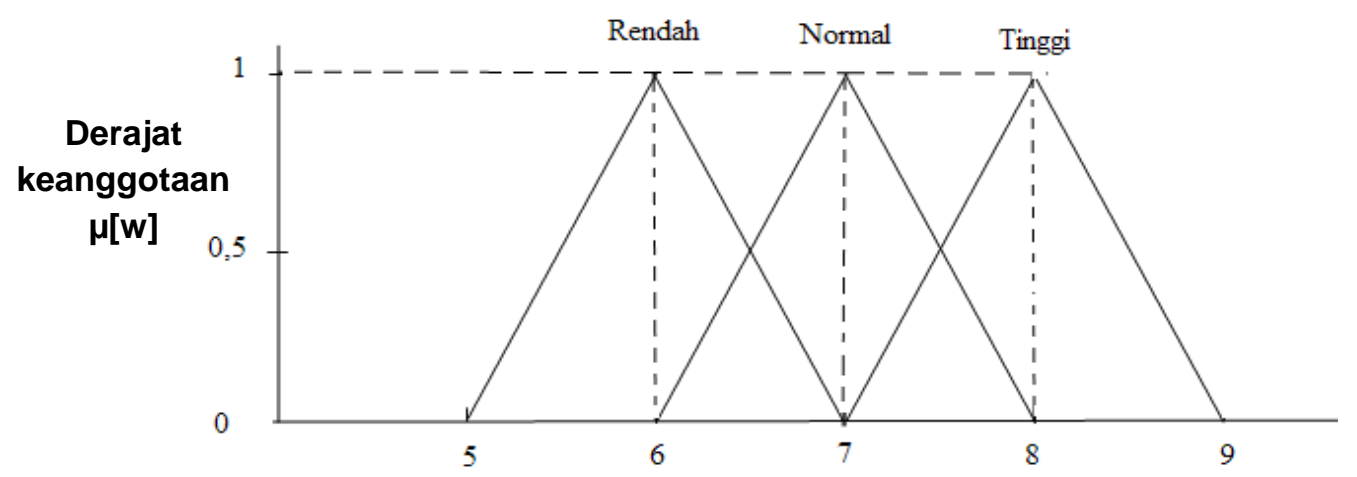

Gambar 2 Representasi variabel Kadar Air

Fungsi

$$
\begin{aligned}
& \mu_{K a}(w)=\left\{\begin{array}{lr}
0 & w \leq a \\
\frac{w-a}{b-a} & \text { atau } w \geq c \\
\frac{a-w}{a-b} & a \leq w \leq b \\
& b \leq w \leq c
\end{array}\right. \\
& \mu_{\text {KaRendah }}(w)=\left\{\begin{array}{lr}
0 ; & w \leq 5 \text { atau } w \geq 7 \\
\frac{w-5}{1} & 5 \leq w \leq 6 \\
\frac{7-w}{1} & 6 \leq w \leq 7
\end{array}\right.
\end{aligned}
$$




$$
\begin{array}{r}
\mu_{\text {RaSziang }}(w)=\left\{\begin{array}{lr}
0, & w \leq 6 \text { atau } w \geq 8 \\
\frac{w-6}{1} & 6 \leq w \leq 7 \\
\frac{8-w}{1} & 7 \leq w \leq 8
\end{array}\right. \\
\mu_{\text {RaTinggi }}(w)=\left\{\begin{array}{lc}
0 ; & 7 \leq \mathrm{ata} w \geq 9 \\
\frac{w-7}{1} & 7 \leq w \leq 8 \\
\frac{9-w}{1} & 8 \leq w \leq 9
\end{array}\right.
\end{array}
$$

Nilai rata-rata kadar air yang berasal dari data aktual adalah 7,025 sehingga;

$>$ Kadar air rendah memiliki domain [5,7], dengan derajat keanggotaan rendah tertinggi adalah 1 terletak pada nilai [6]

$\mu_{R A}$ rendah $(7,025)$

$=$ keluar dari semesta pembicaraan data penelitian

$>$ Kadar air sedang memiliki domain [6,8], dengan derajat keanggotaan sedang tertinggi adalah 1 terletak pada nilai [7] $\mu_{\text {EAA }}$ sedang $(7,025)=0,975$

Kadar air tinggi memiliki domain [7,9], dengan derajat keanggotaan tinggi tertinggi adalah 1 terletak pada nilai [8] $\mu_{K A} \operatorname{ting} g i(7,025)=0,025$

\subsubsection{Jamur}

Dengan menggunakan representasi kurva bentuk segi tiga:

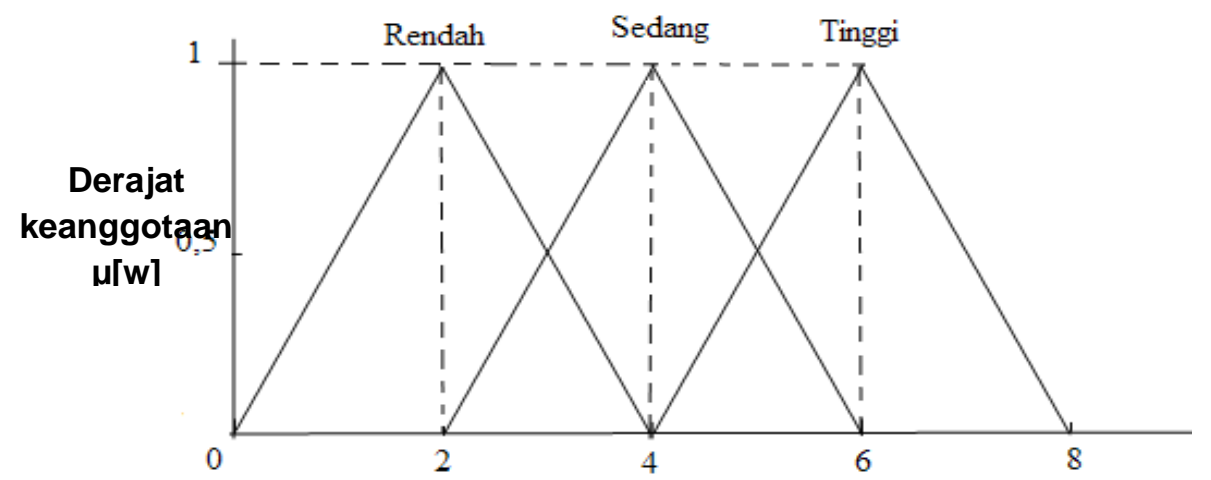

Gambar 3 Representasi variable Jamur

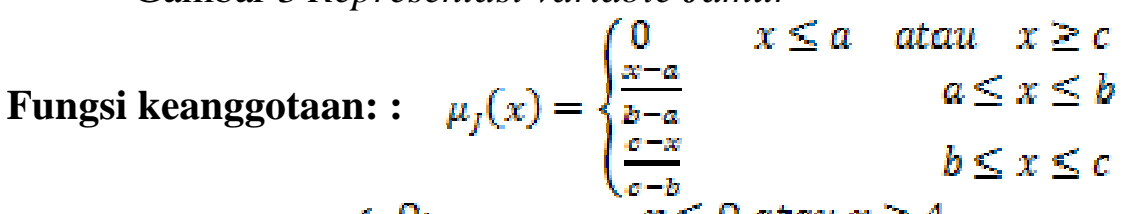

$$
\begin{aligned}
& \mu_{\text {Jindah }}(x)=\left\{\begin{array}{cc}
0 ; & x \leq 0 \text { atau } x \geq 4 \\
\frac{x-0}{2} & 0 \leq x \leq 2 \\
\frac{4-x}{2} & 2 \leq x \leq 4
\end{array}\right.
\end{aligned}
$$




$$
\begin{gathered}
\mu_{\text {JSiang }}(x)=\left\{\begin{array}{lc}
0, & x \leq 2 \text { atau } x \geq 6 \\
\frac{x-2}{2} & 2 \leq x \leq 4 \\
\frac{6-x}{2} & 4 \leq x \leq 6
\end{array}\right. \\
\mu_{\text {JTinggi }}(x)=\left\{\begin{array}{lc}
0 ; & x \leq 4 \text { atau } x \geq 8 \\
\frac{x-4}{2} & 4 \leq x \leq 6 \\
\frac{8-x}{2} & 6 \leq x \leq 8
\end{array}\right.
\end{gathered}
$$

Nilai rata-rata Jamur yang berasal dari data aktual adalah 2,25 sehingga;

$>$ Jamur rendah memiliki domain [0,4], dengan derajat keanggotaan rendah tertinggi adalah 1 terletak pada nilai [2] $\mu_{j}$ rendah $(2,25)=0,875$

$>$ Jamur sedang memiliki domain [2,6], dengan derajat keanggotaan sedang tertinggi adalah 1 terletak pada nilai [4] $\mu_{j}$ sedang $(2,25)=0,125$

Jamur tinggi memiliki domain [4,8], dengan derajat keanggotaan tinggi tertinggi adalah 1 terletak pada nilai [6] $\mu_{j}$ tinggi $(2,25)$

= keluar dari semesta pembicaraan data penelitian

\subsubsection{Kotoran}

Dengan menggunakan representasi kurva bentuk segi tiga:

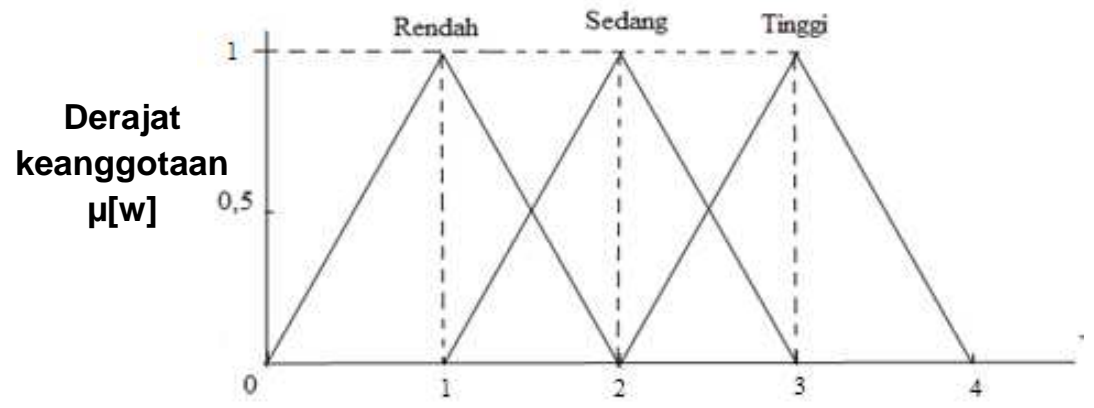

Gambar 4 Representasi variable Kotoran

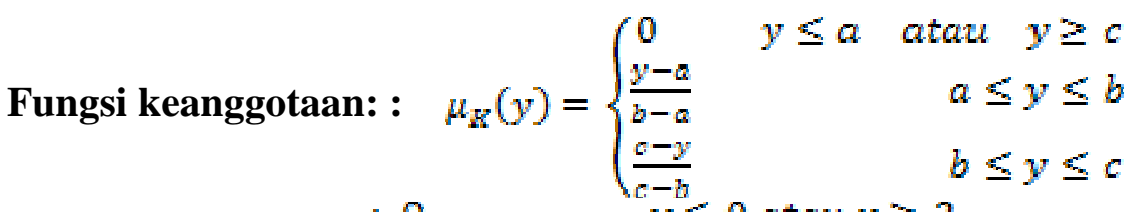

$$
\begin{aligned}
& \mu_{\text {Rendah }}(y)=\left\{\begin{array}{cc}
0 ; & y \leq 0 \text { atau } y \geq 2 \\
\frac{y-0}{1} & 0 \leq y \leq 1 \\
\frac{2-y}{1} & 1 \leq y \leq 2
\end{array}\right.
\end{aligned}
$$




$$
\begin{array}{r}
\mu_{\text {KSidang }}(y)=\left\{\begin{array}{lc}
0, & y \leq 1 \text { atau } y \geq 3 \\
\frac{y-1}{1} & 1 \leq y \leq 2 \\
\frac{3-y}{1} & 2 \leq y \leq 3
\end{array}\right. \\
\mu_{\text {KTinggi }}(y)=\left\{\begin{array}{lc}
0 ; & y \leq 2 \text { atau } y \geq 4 \\
\frac{y-2}{1} & 2 \leq y \leq 3 \\
\frac{4-y}{1} & 3 \leq y \leq 4
\end{array}\right.
\end{array}
$$

Nilai rata-rata Kotoran yang berasal dari data aktual adalah 1 sehingga;

kotoran rendah memiliki domain [0,2], dengan derajat keanggotaan rendah tertinggi adalah 1 terletak pada nilai [1] $\mu_{k}$ rendah $(1)=1$

$>$ kotoran sedang memiliki domain [1,3], dengan derajat keanggotaan sedang tertinggi adalah 1 terletak pada nilai [2]

$\mu_{k} \operatorname{sedan}(1)$

$=$ keluar dari semesta pembicaraan data penelitian

kotoran tinggi memiliki domain [2,4], dengan derajat keanggotaan tinggi tertinggi adalah 1 terletak pada nilai [3] $\mu_{k} \operatorname{tinggi(1)}$

$=$ keluar dari semesta pembicaraan data penelitian

\subsubsection{Biji/100gr}

Dengan menggunakan representasi kurva bentuk segitiga:

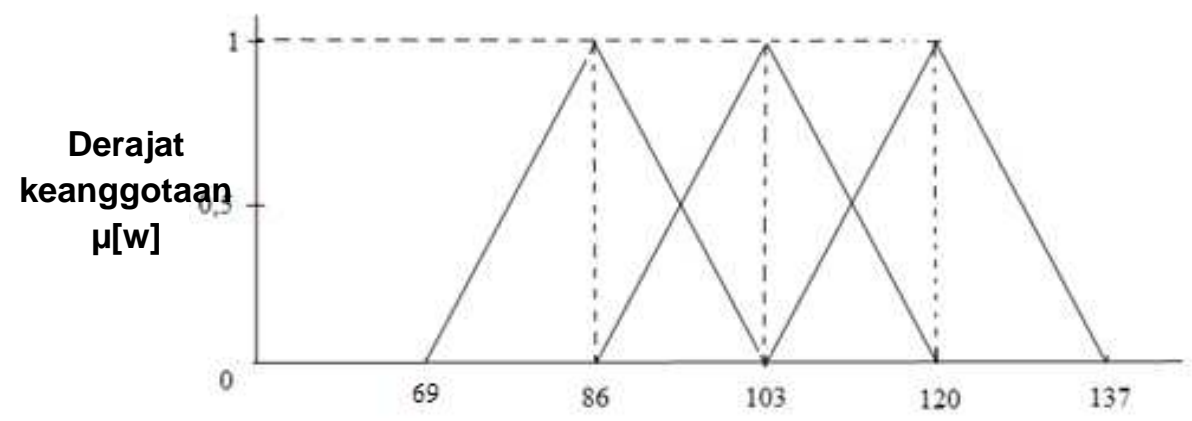

Gambar 5 Representasi variable Biji/100gram

Fungsi

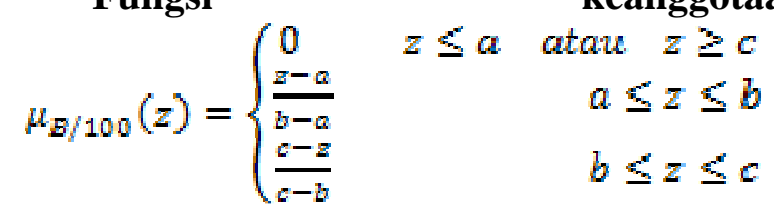




$$
\begin{gathered}
\mu_{E / 100 \text { manah }}(z)=\left\{\begin{array}{lc}
0 ; & z \leq 69 \text { atau } z \geq 103 \\
\frac{z-69}{17} & 69 \leq z \leq 86 \\
\frac{103-z}{17} & 86 \leq z \leq 103
\end{array}\right. \\
\mu_{B / 100 \text { Sedang }}(z)=\left\{\begin{array}{cc}
0 ; & z \leq 86 \text { atau } z \geq 120 \\
\frac{z-86}{17} & 86 \leq z \leq 103 \\
\frac{120-z}{17} & 103 \leq z \leq 120
\end{array}\right. \\
\mu_{B / 100 \text { Tinggi }}(z)=\left\{\begin{array}{cc}
\frac{17}{z-103} & 103 \leq z \leq 120 \\
\frac{137-z}{17} & 120 \leq z \leq 137
\end{array}\right.
\end{gathered}
$$

Nilai rata-rata Kotoran yang berasal dari data aktual adalah 115 sehingga;

$>$ Biji/100gr rendah memiliki domain $[69,103]$, dengan derajat keanggotaan rendah tertinggi adalah 1 terletak pada nilai [86]

$\mu_{B / g}$ rendah(115)

= keluar dari semesta pembicaraan data penelitian

$>$ Biji/100gr sedang memiliki domain [86,120], dengan derajat keanggotaan sedang tertinggi adalah 1 terletak pada nilai [103] $\mu_{B / g r}$ sedang $(115)=0,294$

$>$ Biji/100gr tinggi memiliki domain [103,137], dengan derajat keanggotaan tinggi tertinggi adalah 1 terletak pada nilai [120] $\mu_{B / g^{r}}$ tinggi(115) $=0,706$

\subsubsection{Kualitas}

Untuk mempresentasikan variabel Kualitas digunakan kurva bentuk bahu (untuk himpunan fuzzy Sangat Buruk dan Sangat baik) dan kurva bentuk segitiga (untuk himpunan fuzzy Buruk, Kurang Baik dan Baik).

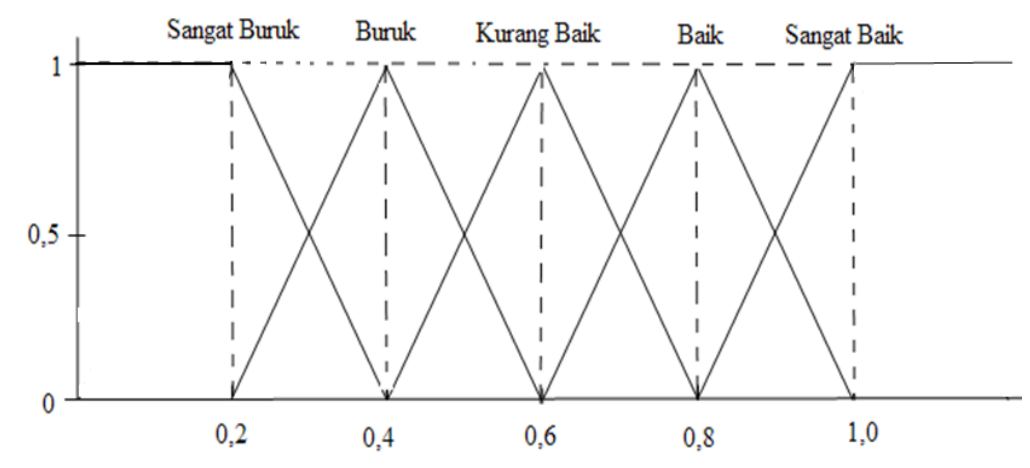

Gambar 6 Representasi variable Hasil 


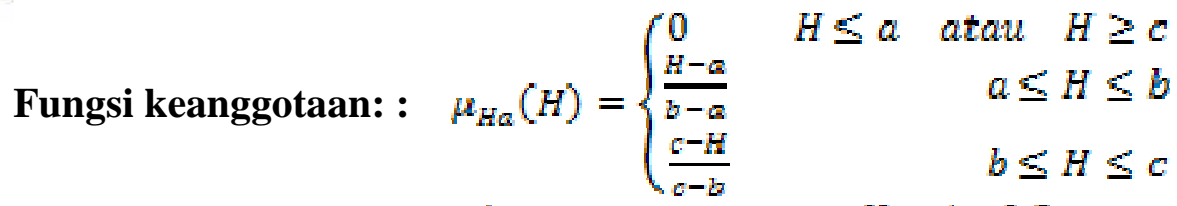

$$
\begin{aligned}
& \mu_{\text {HaSangat Buruk }}(H)=\left\{\begin{array}{c}
1 ; \\
0,4-H \\
\hline 0,2 \\
0
\end{array}\right. \\
& H \leq 0,2 \\
& 0,2 \leq H \leq 0,4 \\
& H \geq 0,4 \\
& \mu_{\text {HaBuruk }}(H)=\left\{\begin{array}{c}
0 ; \\
\frac{H-0,2}{0,2} \\
\frac{0,6-H}{0,2}
\end{array}\right. \\
& H \leq 0,2 \text { atau } H \geq 0,6 \\
& \mu_{\text {HaKurang Baik }}(H)=\left\{\begin{array}{c}
0 ; \\
\frac{H-0,4}{0,2} \\
\frac{0,3-H}{0,2}
\end{array}\right. \\
& H \leq 0,4 \text { atau } H \geq 0,8 \\
& 0,2 \leq H \leq 0,4 \\
& 0,4 \leq H \leq 0,6 \\
& \mu_{\text {Habia }}(H)=\left\{\begin{array}{cc}
0 ; & H \leq 0,6 \text { atau } H \geq 1 \\
\frac{H-0,6}{0,2} & 0,6 \leq H \leq 0,8 \\
\frac{1-H}{0,2} & 0,8 \leq H \leq 1
\end{array}\right. \\
& \mu_{\text {HaSangatbaik }}(H)=\left\{\begin{array}{cl}
0 ; & H \leq 0,8 \\
\frac{H-0,8}{0,2} & 0,8 \leq H \leq 1 \\
1 ; & H \geq 1
\end{array}\right.
\end{aligned}
$$

\section{IMPLEMENTASI SISTEM PAKAR}

Implementasi Sistem Pakar di mulai dengan menampilkan GUI Sistem Pakar Fuzzy dalam M-FILE Matlab dengan nama file Gui_Fuzzy. M-FILE Gui_Fuzzy dapat dilihat pada lampiran 10 dan tampilan dari Gui_Fuzzy dapat dilihat pada gambar berikut:

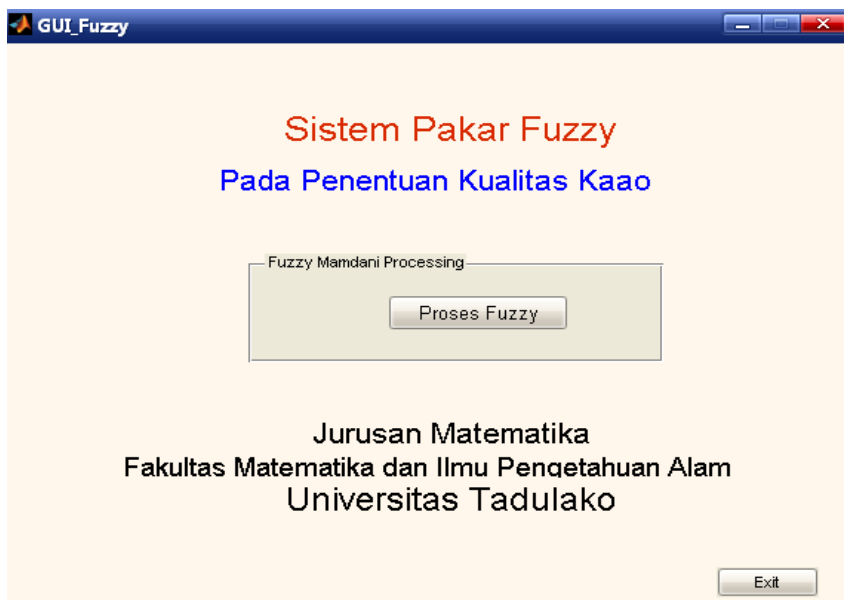

Gambar 7 Tampilan awal GUI 
Pada tampilan GUI_Fuzzy, terdapat dua tombol dengan fungsi yang berbeda yaitu tombol 'Proses Fuzzy' dan Tombol 'Exit'. Tombol 'Proses Fuzzy' berfungsi untuk masuk ke GUI 'Proses Fuzzy' dan tombol 'Exit' berfungsi untuk keluar dari Matlab.

Tahap selanjutnya adalah masuk ke mekanisme proses fuzzy. untuk Tahap ini dilakukan dengan meng-klik kotak 'Proses Fuzzy' seperti yang telah dijelaskan sebelumnya, dan akan muncul tampilan seperti pada gambar 8. Tahap ini melakukan pengolahan data. Pengolahan data dimulai dengan memasukkan nilai kadar air sebesar 7,025, jamur sebesar 1, Kotoran sebesar 225 dan Biji/100 gram sebesar 115. Selanjutnya klik tombol Proses, sehingga akan muncul hasil dan kualitas seperti pada gambar 4.90 berikut:

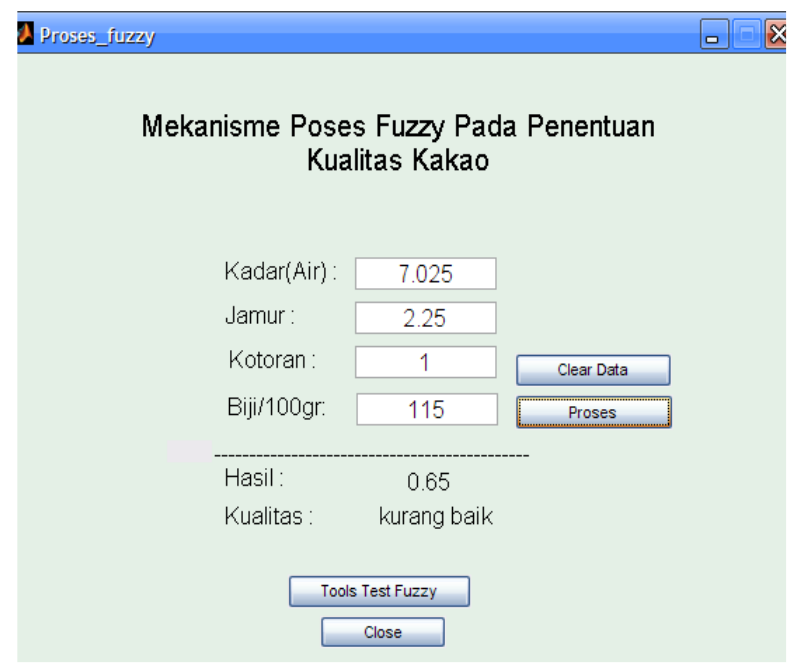

Gambar 8 Hasil dan Kualitas kakao

Untuk pengecekan aplikasi yang dibuat, sesuai dengan rules fuzzy, maka digunakan toolbox Fuzzy Logic pada matlab, agar hasilnya akurat. Pada gambar 9 dijelaskan proses Fuzzy dari input sampai proses dan gambar 10 menampilkan rules dengan penentuan hasil proses fuzzy melalui output kualitas. 


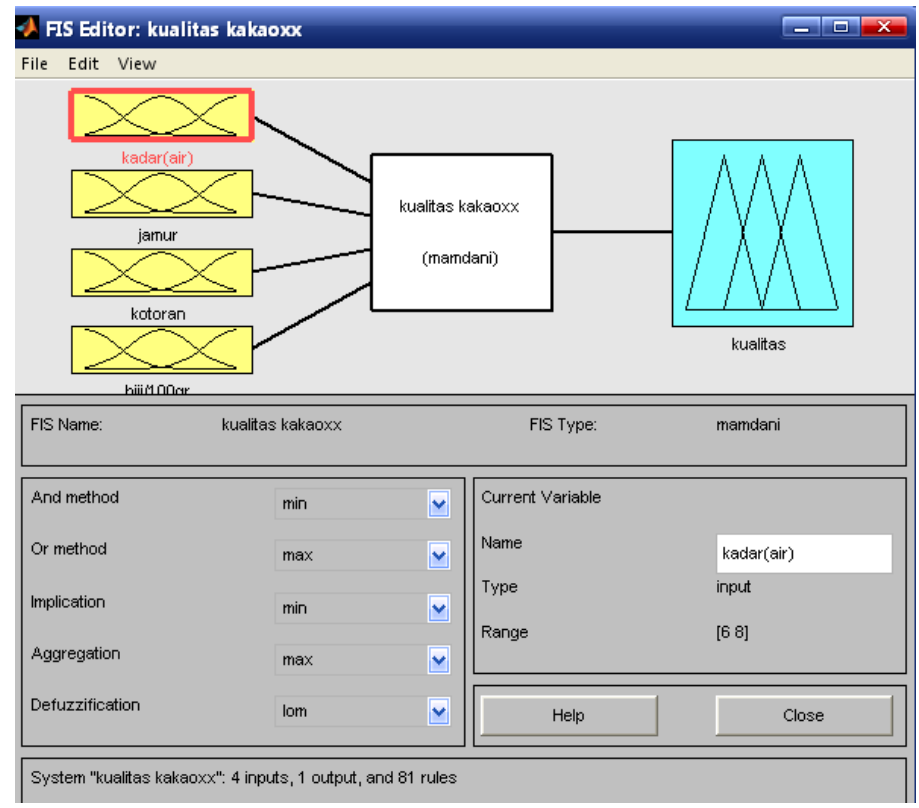

Gambar 9 Proses Fuzzy dengan input, proses, dan output menggunakan Toolbox Matlab

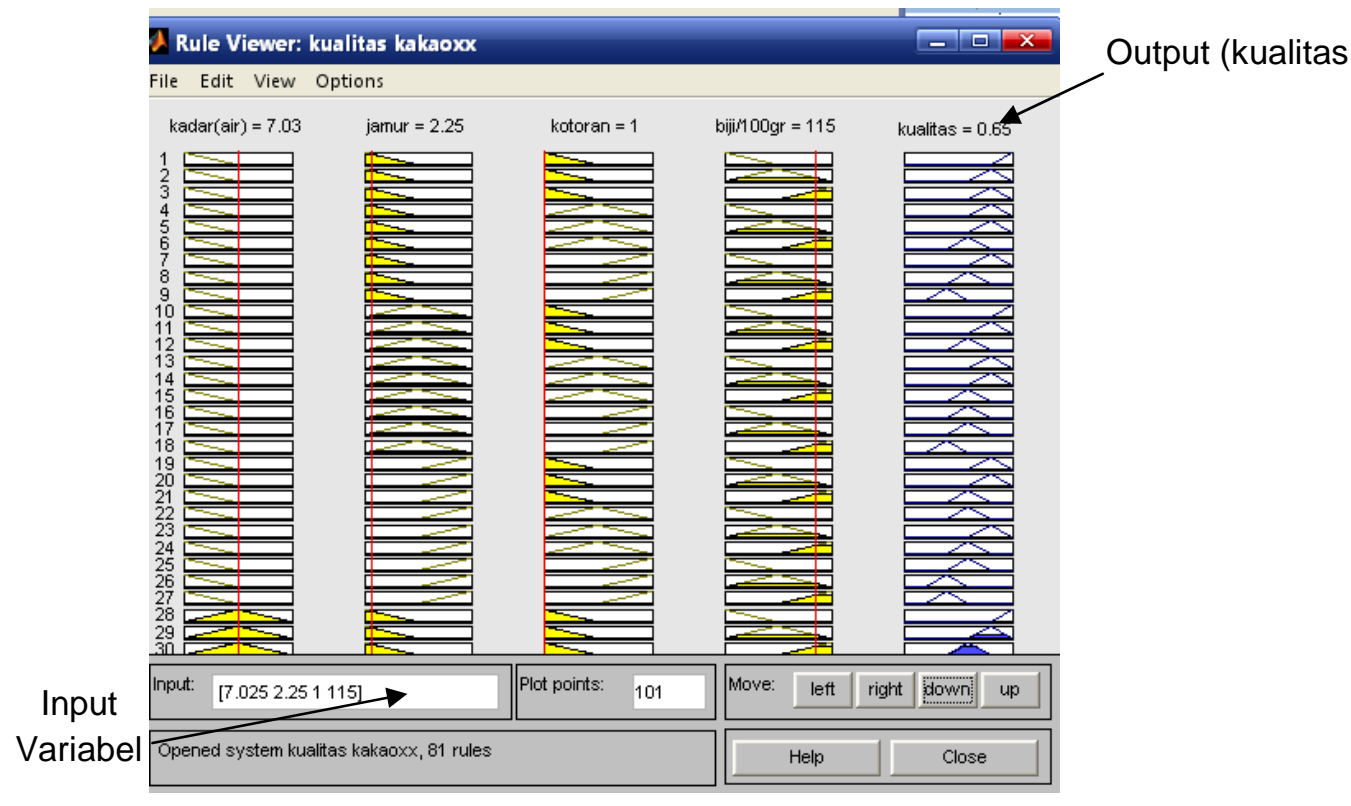

Gambar 10 Penentuan Rules Fuzzy dan Pengujian Sistem dengan Toolbox Matlab

Penentuan kualitas kakao Kabupaten Sigi-Biromaru menggunakan FIS metode mamdani dengan penegasan LOM (Largest Of Maximum) dan input kriteria kadar air sebesar 7,025\%, jamur 2,25\%, kotoran $1 \%$ dan Biji/100gram 115 biji, diperoleh nilai 0,63 . Sedangkan penentuan kualitas kakao dengan input yang sama tetapi menggunakan program MATLAB, diperoleh nilai sebesar 0,65. Perbedaan ini terjadi akibat pembulatan kenilai terdekat yang dilakukan matlab.

Nilai 0,63 yang diperoleh dengan menggunakan FIS metode mamdani dengan penegasan LOM (Largest Of Maximum) maupun nilai 0,65 yang diperoleh dengan 
menggunakan MATLAB, terletak pada himpunan kualitas kurang baik, sehingga dapat disimpulkan bahwa kualitas kakao Kabupaten Sigi-Biromaru adalah kurang baik.

Jika dibandingkan dengan hasil dari pakar berdasarkan standard kualitas kakao (berdasar SNI pada tabel 1) serta di implementasikan melalui rule yang dibuat yaitu:

if (kadar air is sedang) and (jamur is rendah) and (kotoran is sedang) and (Biji/100gr is tinggi) then (kualitas is kurang baik), maka hasilnya akan sesuai.

\section{DAFTAR PUSTAKA}

Dewi,T. and Purnomo H. 2004, "Aplikasi Logika Fuzzy Untuk Pendukung Keputusan."Graha Ilmu, Yogyakarta.

http://www.akademik.unsri.ac.id/ PERSPEKTIF AGRIBISNIS KAKAO DI SULAWESI TENGGARA. Di akses pada tanggal 28 maret 2011. http://www.docstoc.com/SISTEM-PAKAR-FUZZY-PENENTUAN-DANPENIGKATAN-KUALITAS-MANGGIS-Fuzzy. diakses pada tanggal 26 januari 2011.

Kusumadewi,S.2003, “Artificial Intelligence(Teknik dan Aplikasinya)." Graha Ilmu, Yogyakarta.

Mayang, I.T. 2010, "Prediksi Varietas Unggul Dari Model Dinamik Persilangan Tanaman Coklat." Skripsi, Palu.

Susilo,F. 2006, "Himpunan dan logika Kabur Serta Aplikasinya."Graha Ilmu, Yogyakarta. 